\title{
A Stem-nodulating Rhizobium with Physiological Characteristics of Both Fast and Slow Growers
}

\author{
By MARK D. STOWERS† AND ALLAN R. J. EAGLESHAM* \\ Boyce Thompson Institute for Plant Research at Cornell University, Ithaca, New York 14853, U.S.A.
}

(Received 7 February 1983; revised 14 June 1983)

\begin{abstract}
Rhizobium strain BTAi 1 which was isolated from a stem nodule on Aeschynomene indica was a fast grower with mean generation times of 3.2 and $4.0 \mathrm{~h}$ with glucose and mannitol, respectively. Its ability to utilize sucrose and lactose confirmed the similarity of BTAi 1 to other fast growers. However, its inability to utilize rhamnose, dulcitol, raffinose, trehalose, citrate, malate and fumarate linked it to the slow-growing rhizobia. The absence of the pentose phosphate pathway also placed BTAi 1 with the slow-growers as did the presence of 2-keto-3-deoxy-L-arabonate aldolase, its small colony morphology and the production of alkali with most carbon sources. Strain BTAi 1 is thus an intermediate type of Rhizobium, sharing characteristics with both fast and slow growers.
\end{abstract}

\section{INTRODUCTION}

There is much information regarding the biology of economically important Rhizobiumlegume associations, but little is available concerning the more obscure interactions, such as the stem nodule symbiosis of Aeschynomene species (Yatazawa \& Yoshida, 1979).

Any future study of the Rhizobium-Aeschynomene symbiosis must be complemented by basic information regarding the physiology of the microsymbiont. Little is known of the physiology of Aeschynomene root- or stem-nodule isolates (Allen \& Allen, 1981; Subba Rao et al., 1980; Yatazawa \& Yoshida, 1979), but they appear to belong to the slow-growing group of rhizobia probably in the cowpea miscellany (Allen \& Allen, 1981; Date \& Halliday, 1980). Stem nodules also occur on Sesbania rostrata (Dreyfus \& Dommergues, $1981 a, b$ ) and the infecting Rhizobium is reported to be fast-growing (Y. R. Dommergues, personal communication).

Rhizobia are classified primarily as fast or slow growers in yeast extract/mannitol broth (Allen \& Allen, 1950; Jordan \& Allen, 1974) and on their enzymes of carbon metabolism (Martinez-De Drets \& Arias, 1972). In order to establish the fundamental characteristics of these stem-nodulating rhizobia for comparison with other types, this communication describes nutritional and enzymic studies.

\section{METHODS}

Rhizobia. Rhizobium strain BTAi 1, was isolated from a submerged stem nodule on greenhouse-grown Aeschynomene indica (Eaglesham \& Szalay, 1983). These nodules were discovered on $A$. indica plants grown in nonsterilized sand from surface-sterilized seeds, but did not occur on plants grown in sterilized sand. We concluded that the rooting medium (quartz sand from the Pennsylvania Glass Sand Corporation, Pittsburgh, U.S.A.) was the source of the rhizobia. The sand had been mined as quartzite from an open pit mine in West Virginia with contamination from surface soil (J. McDonough, personal communication). It may be significant that $A$. virginica

† Present address: Native Plants, Salt Lake City, Utah 84108, U.S.A.

Abbreviations: KDA aldolase, 2-keto-3-deoxy-L-arabonate aldolase; PFK, phosphofructokinase; 6PG dehydrogenase/dehydratase, 6-phosphogluconate dehydrogenase/dehydratase. 
is indigenous from New Jersey to S. E. Virginia (Gleason, 1952). Strain BTAi 1 nodulated the roots as well as the stems of several Aeschynomene species (Eaglesham \& Szalay, 1983).

The isolate was maintained on agar slants and transferred every three months. Infectivity was checked on the stems of $A$. scabra on which nodules appeared 4-6 d after inoculation (Eaglesham \& Szalay, 1983).

Rhizohium sp. strain IRc 256 was obtained from the IITA Collection of Cultures of Rhizobium, Ibadan, Nigeria, and Rhizohium sp. strain $32 \mathrm{H} 1$ from the Nitragin Co., Milwaukee, Wis., U.S.A. These are slow-growing strains of the cowpea miscellany: IRc 256 was isolated from Vigna unguiculata and $32 \mathrm{H} 1$ from Crotolaria paulina. Rhizobium leguminosarum strain ATCC 10004 was obtained from the American Type Culture Collection, Rockville, Md., U.S.A

Media. The basal growth medium consisted of the following $\left(\mathrm{g}^{\cdot 1}\right): \mathrm{K}_{2} \mathrm{HPO}_{4}, 0 \cdot 5 ; \mathrm{MgSO}_{4}, 7 \mathrm{H}_{2} \mathrm{O}, 0 \cdot 8 ; \mathrm{NaCl}$, $0 \cdot 2: \mathrm{FeCl}_{3} \cdot 6 \mathrm{H}_{2} \mathrm{O}, 0 \cdot 01 ;$ mannitol, 10 ; yeast extract, $1 \cdot 0$; and, for solidified medium, agar was added to a final concentration of $2 \%(w / v)$ (Norris \& Date, 1976). When other carbon sources replaced mannitol, they were either autoclaved separately (galactose, gluconate, glycerol, mannose, rhamnose and xylose) or filter sterilized (arabinose, citrate, fructose, fumarate, glucose, malate, pyruvate, raffinose, succinate and trehalose) and then added to the medium to a final concentration of $1 \%(w / v)$.

Cultural conditions. All broths and agar plates were incubated at $28-30^{\circ} \mathrm{C}$. Inocula for agar plates were from agar slants. Inocula for broth cultures were from primary broth cultures harvested by centrifugation, washed once with cold, sterile $50 \mathrm{~mm}$-sodium phosphate buffer $\mathrm{pH} 7.0$ and then added to a final concentration of $2 \%(\mathrm{v} / \mathrm{v})$. Generation times were determined from exponential phase cells by viable counts.

Nutritional characteristics. Carbon nutrition was determined using an agar-plate method with the basal growth medium and yeast extract and the appropriate carbon source. Growth on control plates was attributed to the utilization of yeast extract as the sole carbon source. Growth with a particular carbon source was determined after $5 \mathrm{~d}$ by comparison with control agar plates where the major carbon source was omitted. The analysis of growth by this method was required since strain BTAi 1 did not grow well on inorganic nitrogen. Acid or alkali production was determined by colour change of bromthymol blue, which was incorporated into the agar medium at a final concentration of $0.00125 \%(\mathrm{w} / \mathrm{v})$.

Preparation of cell-free extracts. Cells were harvested by centrifugation, washed twice in cold 50 mM-sodium phosphate buffer $\mathrm{pH} \mathrm{7.0,} \mathrm{and} \mathrm{resuspended} \mathrm{in} \mathrm{cold} 50 \mathrm{~mm}$-sodium phosphate $\mathrm{pH} 7 \cdot 0$, containing $1 \mathrm{mm-EDTA}$. The cells were disrupted by sonication (Braun Sonicator), with three one-minute treatments with $15 \mathrm{~s}$ intervals. Cell debris was removed by refrigerated centrifugation at $35000 \mathrm{~g}$ for $30 \mathrm{~min}$. Cell-free extracts were obtained by collecting the clear supernatant. Protein was determined using the method of Bradford (1976) and adjusted to $1 \cdot 0$ $5.0 \mathrm{mg} \mathrm{ml}^{-1}$.

Enzyme assays. Published procedures were used to assay glucose-6-phosphate (G6P), 6-phosphogluconate (6PG) dehydrogenases (EC 1.1.1.49 and 1.1.1.44, respectively) and phosphofructokinase (PFK) EC 2.7.1.11) (Stowers \& Elkan, 1983), isocitrate dehydrogenase and malate dehydrogenase (EC 1.1.1.42 and EC 1.1.1.37, respectively) (Rokosh et al., 1973) and 2-keto-3-deoxy-L-arabonate (KDA) aldolase (EC 4.1.2.18) (Pedrosa \& Zancan, 1974). The Entner-Doudoroff enzymes were determined as the coupled activity of 6PG dehydratase (EC 4.2.1 . 12) and 2-keto-3-deoxy-6-phosphogluconate aldolase (EC 4.L.2.14) as described by Lessie \& Vander Wyk (1972).

\section{RESULTS}

\section{Growth and nutritional characteristics}

After $7 \mathrm{~d}$ growth on yeast mannitol agar, colonies of BTAi 1 were less than $1 \mathrm{~mm}$ in diameter, circular with an entire margin and white with a slightly convex elevation. This type of colony morphology is typical of the slow-growing rhizobia (Graham \& Parker, 1964).

Strain BTAi 1 grew best on hexoses, but also used pentoses, glycerol and the disaccharides, sucrose and lactose (Table 1). It was unable to use the TCA cycle intermediates malate and fumarate and grew poorly on succinate. Acid production occurred only with arabinose and xylose, whereas the other carbon sources caused increases in $\mathrm{pH}$. For comparison, the nutritional characteristics of the fast-grower $R$. leguminosarum strain ATCC 10004 and the slowgrower Rhizobium sp. IRc 256 are included in Table 1 to show patterns typical of fast and slow growers (Vincent, 1977). Marked similarities were found between BTAi 1 and IRc 256. Both strains failed to use rhamnose, dulcitol, raffinose, trehalose, citrate, malate and fumarate. In contrast, ATCC 10004 used all these compounds. The final culture $\mathrm{pH}$ reactions were almost identical with BTAi 1 and IRc 256, but with strain ATCC 10004 only acid reactions were obtained. 
Table 1. Carbohydrate nutritional characteristics of Rhizobium strain BTAi 1 in comparison to Rhizobium sp. strain IRc 256 and R. leguminosarum strain ATCC 10004

+ , Better growth than in the control without carbon: -, growth equal to the control without carbon: alkaline, $\mathrm{pH}>6.8$, or blue reaction with bromthymol blue; acid, $\mathrm{pH}<6 \cdot 8$, or yellow reaction with bromthymol blue.

\begin{tabular}{|c|c|c|c|c|c|c|}
\hline \multirow{2}{*}{$\begin{array}{c}\text { Carbon } \\
\text { source }\end{array}$} & \multicolumn{2}{|c|}{$\begin{array}{l}\text { Strain } \\
\text { BTAi } 1\end{array}$} & $\begin{array}{r}\text { Rhizobium } \\
\text { (Slow }\end{array}$ & $\begin{array}{l}\text { sp. IRc } 256 \\
\text { grower) }\end{array}$ & $\begin{array}{r}\text { R. legun } \\
\text { ATCC } \\
\text { (Fast }\end{array}$ & $\begin{array}{l}\text { minosarum } \\
\text { C } 10004 \\
\text { grower) }\end{array}$ \\
\hline & Growth & Final $\mathrm{pH}$ & Growth & Final pH & Growth & Final $\mathrm{pH}$ \\
\hline Glucose & + & Alkaline & + & Alkaline & + & Acid \\
\hline Fructose & + & Alkaline & + & Alkaline & + & Acid \\
\hline Galactose & + & Alkaline & + & Alkaline & + & Acid \\
\hline Gluconate & + & Alkaline & + & Alkaline & + & Acid \\
\hline Mannose & + & Alkaline & + & Alkaline & + & Acid \\
\hline Mannitol & + & Alkaline & + & Alkaline & + & Acid \\
\hline Rhamnose & - & - & - & - & + & Acid \\
\hline Dulcitol & - & - & - & - & + & Acid \\
\hline Arabinose & + & Acid & + & Acid & + & Acid \\
\hline Xylose & + & Acid & + & Acid & + & Acid \\
\hline Raffinose & - & - & - & - & + & Acid \\
\hline Sucrose & + & Alkaline & - & - & + & Acid \\
\hline Lactose & + & Alkaline & - & - & + & Acid \\
\hline Trehalose & - & - & - & - & + & Acid \\
\hline Glycerol & + & Alkaline & + & Alkaline & + & Acid \\
\hline Pyruvate & - & Alkaline & - & - & + & Acid \\
\hline Citrate & - & - & - & - & + & Acid \\
\hline Succinate & + & Alkaline & - & - & + & Acid \\
\hline Malate & - & - & - & - & + & Acid \\
\hline Fumarate & $\rightarrow$ & - & - & - & + & Acid \\
\hline
\end{tabular}

Table 2. Specific activities of carbohydrate-catabolizing enzymes in cell-free extracts of Rhizobium strain BTAi 1 and generation times, when cultured on various carbon sources

Carbon and energy sources were used at a final concentration of $1 \%(w / v)$. Specific activities are expressed as IU (mg protein) ${ }^{-1}$.

\begin{tabular}{lccccc} 
Enzyme & \multicolumn{5}{c}{ Carbon source } \\
\cline { 2 - 6 } phate dehydrogenase & Glucose & Mannitol & Sucrose & Arabinose & Succinate \\
nate dehydrogenase & 0.026 & 0.024 & 0.020 & 0.021 & 0.013 \\
& NDA & NDA & NDA & NDA & NDA \\
inase & $0 \cdot 150$ & 0.200 & 0.122 & 0.121 & 0.095 \\
L-arabonate aldolase & NDA & NDA & NDA & NDA & NDA \\
drogenase & ND & ND & ND & 0.078 & ND \\
genase & 0.484 & 0.521 & 0.487 & 0.502 & 0.781 \\
mes (h) & 0.880 & 0.891 & 0.752 & 0.674 & 0.991 \\
& 3.2 & 4.0 & 4.8 & 7.8 & $9 \cdot 1$
\end{tabular}

Glucose-6-phosphate dehydrogenase

6-Phosphogluconate dehydrogenase

'ED' enzyme*

Phosphof ructokinase

2-keto-3-deoxy-L-arabonate aldolase

Isocitrate dehydrogenase

Malate dehydrogenase

Generation times (h)

ND, Not determined

NDA, No detectable activity.

* ED enzyme is the combined activity of 6-phosphogluconate dehydratase and 2-keto-3-deoxy-6-phosphogluconate aldolase.

Strain BTAi 1 had the fastest growth rate with glucose, with a generation time of $3 \cdot 2 \mathrm{~h}$ (Table 2). When growing with mannitol, its generation time was $4.0 \mathrm{~h}$ (Table 2), comparable to the $2.8 \mathrm{~h}$ obtained with strain ATCC 10004 . The growth rates of BTAi 1 were faster than expected based on its carbon nutrition patterns and final culture alkaline $\mathrm{pH}$ reactions, which were 
characteristic of slow-growing rhizobia, i.e. those with generation times exceeding $6 \mathrm{~h}$ (Jordan \& Allen, 1974; Vincent, 1977). Strain IRc 256 had a generation time of $9.3 \mathrm{~h}$ with mannitol. Strain BTAi 1 had its slowest growth rate when cultured with succinate (Table 2) and it is interesting to note that the highest growth rates previously reported for fast-growing rhizobia have been with succinate (Ucker \& Signer, 1978).

\section{Enzymes of carbon metabolism}

There was no evidence for the presence of the pentose phosphate pathway, since cell-free extracts lacked the NADP-linked 6PG dehydrogenase (Table 2). Likewise, no activity was detected for PFK indicating the lack of the Embden-Meyerhof-Parnas pathway. Therefore, the sole routes of metabolism of mannitol, glucose and sucrose were by the Entner-Doudoroff pathway and the TCA cycle, the former revealed by the G6P dehydrogenase and EntnerDoudoroff enzyme activities and the latter by the isocitrate and malate dehydrogenase activities. Extracts from Rhizobium sp. $32 \mathrm{H} 1$ were run simultaneously as controls, and enzyme activities were identical to those previously reported (Stowers \& Elkan, 1983). The pathway for arabinose catabolism was the same as that described for slow-growing Rhizobium japonicum as shown by the presence of KDA aldolase (Pedrosa \& Zancan, 1974).

\section{DISCUSSION}

A stem-nodule Rhizobium previously isolated from Aeschynomene indica strain BTAi 1 (Eaglesham \& Szalay, 1983), was the subject of this study. It was chosen for its ability to nodulate only Aeschynomene species (Legocki et al., 1983) hence exemplifying the characteristics of rhizobia which form the unusual stem nodule symbiosis.

Strain BTAi 1 showed metabolic characteristics which are common to both fast- and slowgrowing rhizobia, such as the absence of the Embden-Meyerhof-Parnas pathway and the presence of the Entner-Doudoroff pathway and TCA cycle for carbon catabolism (Martinez-De Drets \& Arias, 1972; Elkan \& Kuykendall, 1982). Past attempts to delineate rhizobia have resulted in two main groupings based primarily on growth rate and final culture $\mathrm{pH}$ of cells grown in yeast extract/mannitol broth (reviewed by Vincent, 1977). Acid production has been linked to fast-growing rhizobia and alkali production to slow-growing rhizobia (Norris, 1965). The alkaline reactions observed with BTAi 1 (Table 1) were characteristic of slow-growing rhizobia (Jordan \& Allen, 1974). Enzymic differences have also contributed to the distinction of fast and slow growers (Martinez-De Drets \& Arias, 1972).

The growth rate of BTAi 1 and its ability to utilize disaccharides for growth placed it with the fast-growing rhizobia (Jordan \& Allen, 1974; Vincent, 1977). On the other hand, the colony morphology, the alkaline final culture $\mathrm{pH}$, inability to use TCA cycle intermediates as sole carbon source, the absence of an NADP-linked 6PG dehydrogenase, and the presence of an arabinose catabolic pathway possessing KDA aldolase and an acid end product, grouped this isolate with slow-growing rhizobia (Jordan \& Allen, 1974; Vincent, 1977). In contrast, the Sesbania stem nodule bacterium, ORS 571, did not grow with mannitol as the sole carbon source and preferred TCA cycle intermediates for growth (Y.R. Dommergues, personal communication).

This Rhizobium strain which nodulates the stems of Aeschynomene species is an example of an intermediate type sharing physiological properties of both fast and slow growers. Another intermediate-type Rhizobium isolated from Leucaena leucocephala, has recently been reported (Tan \& Broughton, 1981). With regard to growth rate, acid production and carbohydrate utilization patterns it was characterized as a fast grower, while it had a metabolic preference for glutamate as nitrogen source, a characteristic usually found in slow growers (Tan \& Broughton, 1981, 1982). In addition, this isolate possessed a single sub-polar flagellum, as did strain BTAi 1 , (M. D. Stowers \& A. R. J. Eaglesham, unpublished) linking it to the slow-growing group of rhizobia. It is clear that the separation between fast- and slow-growing rhizobia is not as distinct as once thought.

We thank Suzette Payne for typing the manuscript. 


\section{REFERENCES}

Allen, E. K. \& Allen, O. N. (1950). Biochemical and symbiotic properties of the rhizobia. Bacteriological Reviews 14, 273-330.

Allen, E. K. \& Allen, O. N. (1981). The Leguminosae, pp. 21-25. Madison: University of Wisconsin Press.

BRADFORD, M. M. (1976). A rapid and sensitive method for the quantitation of microgram quantities of protein utilizing the principle of protein-dye binding. Analytical Biochemistry 72, 248-254.

Date, R. A. \& Halliday, J. (1980). Relationships between Rhizobium and tropical forage legumes. In Advances in Legume Science, pp. 597-601. Edited by R. J. Summerfield \& A. H. Bunting. Kew: Royal Botanic Gardens.

DREYFUS, B. L. \& DOMmergues, Y. R. (1981 $a$ ). Stem nodules on the tropical legume, Sesbania rostrata. In Current Perspectives in Nitrogen Fixation, p. 471. Edited by A. H. Gibson \& W. E. Newton. Canberra: Australian Academy of Sciences.

DREYFus, B. L. \& DOMMERGUES, Y. R. (1981 b). Nitrogen-fixing nodules induced by Rhizobium on the stem of the tropical legume Sesbania rostrata. FEMS Letters 10, 313-317.

Eaglesham, A. R. J. \& Szalay, A. A. (1983). Aerial stem nodules on Aeschynomene spp. Plant Science Letters 29, 265-272.

Elkan, G. H. \& Kuykendall, L. D. (1982). Energy metabolism in Rhizobium. In Nitrogen Fixation Volume 2: Rhizobium, pp. 147-166. Edited by W. J. Broughton. Oxford: Oxford University Press.

Gleason, H. A. (1952). New Britton and Brown Illustrated Flora, vol. 2, p. 437. Pennsylvania: Lancaster Press.

Graham, P. H. \& Parker, C. A. (1964). Diagnostic features in the characterization of the root-nodule bacteria of legumes. Plant and Soil 20, 383-396.

JoRdAN, D. C. \& AlLEN, O. N. (1974). Rhizobiaceae. In Bergey's Manual of Determinative Bacteriology, 8th edn, pp. 261-267. Edited by R. E. Buchanan \& N. E. Gibbons. Baltimore: Williams \& Wilkins.

Legocki, R., Eaglesham, A. R. J. \& Szalay, A. A. (1983). Stem nodulation in Aeschynomene: a model system for bacterium-plant interactions. In Proceedings of the First International Symposium on Molecular Genetics of the Bacteria-Plant Interaction. Edited by A. Puhler. Berlin: Springer Verlag (in the Press).

Lessie, T. G. \& VANDER WyK, J. C. (1972). Multiple forms of Pseudomonas multivorans glucose-6-phosphate and 6-phosphogluconate dehydrogenases: differences in size, pyridine nucleotide specificity and susceptibility to inhibition by adenosine-5-triphosphate. Journal of Bacteriology 110, 1107-1117.

Martinez-De Drets, G. \& ARIas, A. (1972). Enzymatic basis for differentiation of Rhizobium into fastand slow-growing groups. Journal of Bacteriology $109,467-470$.

NoRRIS, D. O. (1965). Acid production by Rhizobium. A unifying concept. Plant and Soil 22, 143-166.

NoRris, D. O. \& DATE, R. A. (1976). Legume bacteriology. In Tropical Pasture Research: Principles and Methods, pp. 134-174. Edited by N. H. Shaw \& W. W. Bryan. Canberra: Bulletin 51, Commonwealth Agricultural Bureau.

Pedrosa, F. O. \& Zancan, G. T. (1974). L-Arabinose metabolism in Rhizobium japonicum. Journal of Bacteriology 119, 336-338.

Rokosh, D. A., Kurz, W. G. W. \& LaRue, T. A. (1973). A modification of isocitrate and malate dehydrogenase assays for use in crude cell free extracts. Analytical Biochemistry 54, 477-483.

StOWERS, M. D. \& ElKan, G. H. (1983). The transport and metabolism of glucose in cowpea rhizobia. Canadian Journal of Microbiology 29, 398-406.

Subba Rao, N. S., Tilak, K. V. B. R. \& Singh, C. S. (1980). Root nodulation studies in Aeschynomene aspera. Plant and Soil 56, 491-494.

TAN, I. K. P. \& Broughton, W. J. (1981). Rhizobia in tropical legumes - XIII. Biochemical basis of acid and alkali reactions. Soil Biology and Biochemistry 13, 389-393.

TAN, I. K. P. \& Broughton, W. J. (1982). Rhizobia in tropical legumes - XIV. Ion uptake differences between fast- and slow-growing strains. Soil Biology and Biochemistry 14, 295-299.

UCKer, D. S. \& SIGNER, E. R. (1978). Cataboliterepression-like phenomenon in Rhizobium meliloti. Journal of Bacteriology 136, 1197-1200.

VINCENT, J. M. (1977). Rhizobium: general microbiology. In $A$ Treatise on Dinitrogen Fixation Section III: Biology, pp. 277-366. Edited by R. W. F. Hardy \& W. S. Silver. New York: Wiley.

YATAZAWA, M. \& Yoshida, S. (1979). Stem nodules in Aeschynomene indica and their capacity of nitrogen fixation. Physiologia plantarum 45, 293-295. 